\title{
大腸粘膜下浸潤癌の臨床病理学的分析とその治療方針
}

\author{
新潟大学第 1 外科 \\ 下田 聡 武藤 輝一 畠山 勝義 \\ 井上雄一朗須田 武保

\section{CLINICOPATHOLOGICAL ANALYSIS AND MANAGEMENT OF EARLY COLORECTAL CANCER WITH SUBMUCOSAL INVASION}

\section{Satoshi SHIMODA, Terukazu MUTO, Katsuyoshi HATAKEYAMA, Yuichiro INOUE and Takeyasu SUDA} \\ The First Department of Surgery, Niigata University School of Medicine
}

\begin{abstract}
大腸 $\mathrm{sm}$ 癌切除例117例, 123病巣を対象として臨床病理学的分析および治療方針につき検討した. 予 後悪性因子陽性率はリンパ節転移 $9.4 \%$ ，リンパ管侵墏 $21.4 \%$ ，静脈侵襲 $19.7 \%$ でありわれわれが提唱 した sm 浸潤度分類とよく相関していた. sm 癌に対する治療は術後機能障害と分析結果より結腸およ

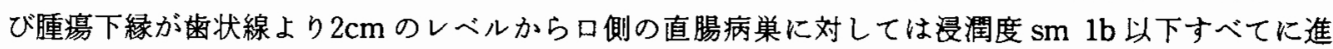

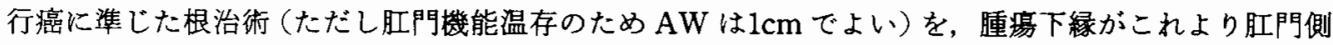
の直腸病巣に対しては直腸切断術の適応とするがその施行条件は脈管侵襲陽性，低分化腺癌あるいは 未分化癌， sm 3とするのが妥当と考えられた。
\end{abstract}

索引用語：大腸 $\mathrm{sm}$ 癌，大腸 $\mathrm{sm}$ 癌漫潤度分類，大腸 $\mathrm{sm}$ 癌治療方針

はじめに

近年の大腸癌症例増加傾向に伴って早期発見の努力 がなされた結果, われわれが早期癌に遭遇する機会が 多くなってきた。粘膜内癌 (以下 $\mathrm{m}$ 癌) に関しては文 献上転移の報告がないことからその治療はポリペクト ミ一ないし局所切除で十分とされているが，粘膜下浸 潤癌(以下 $\mathrm{sm}$ 癌)に関しては $10 \%$ 前後の頻度でリンパ 節転移が, 数\%の頻度で肝転移が見られ，どの程度の 治療が必要とされるかはいまだ論議の多いところであ る.特に sm 癌の頻度の高い直腸の場合は術後機能障 害の点から必要最小限の切除が望まれるが，それには 転移の危険性が原発巣より正確に推定出来なければな らない. 1952年, Lockhart-Mummery and Dukesは その著書のなかで原発巣の組織悪性度と sm 領域にお ける癌の広がりが治療方針を決定する上で重要である と発表した ${ }^{1)}$. 以来これに関連した数多くの論文が出 されているが結論は一定せず，いまだ転移の危険性を 予測する決定的な因子を見いだすことが出来ていな

$<1988$ 年12月14日受理 >別刷請求先：下田 聡 $\overline{\mathbf{T}} 951$ 新潟市旭町通 $1-757$ 新渴大学医学部第 1 外 科
いここのため一定の条件下にポリペクトミーだけでよ いとする報告2) 文がある一方でそれだけでは危険だと 主張する意見も根強く残っている5) 7). 各論文におい て結論が一定しない大きな原因の一つとして各施設で 経験できる症例数が少ないことが考兄られる.1983年, 武藤汭は27施設を対象としたアンケートより393例, 400病巣を集計しその分析結果を報告しているが,これ はわれわれに数多くの情報をもたらした。当科です以 前より関連施設の協力を得て $\mathrm{sm}$ 癌の集積に努め，そ の臨床病理学的な検討より独自の治療方針を決定して 来た. 今回, この集積例が100例を越えるに当たりその 分析結果の報告と，これに基づき現在われわれが採用 している治療方針についても述べてみたい。

\section{対象と方法}

過去22年間に当科および関連施設で切除された進行 癌合併のないsm 癌117例, 123病巣を対象とした(ただ し大腸進行癌および他臟器癌の根治手術後 5 年以上経 過し再発の無い症例を含む).原発巣の組織学的検索に は 1 病巣当り最大割面 1 切片(HE 染色)を用いた。 た局所切除例が 6 例含まれて招り（いずれも経過 5 年 未満）リンパ節転移の有無が不明のため,リンパ節転 
移に関する検索対象はこれら 6 例を除いた111例，117 病巣とした。 また $\mathrm{sm}$ 癌との比較検討対象として $\mathrm{m}$ 癌 65例67病巣（当科における切除例および当院内視鏡部 のポリペクトミー症例), $\mathrm{pm}$ 癌182例182病巣（当科抒 よび関連施設切除例)，ss， a 1 以下の進行癌 397 例404病 巣(当科切除例)を用いた。 $\mathrm{sm}$ 癌の平均年齢は62.0歳, その男女比は55：62であった。これを他の群と比較し 表に示寸(表 1，2). な和本論文の大腸癌に関する分 類ならびに記載は大腸癌取り扱い規約9 に従った，肉 眼形態に関しては茥の有無を基準として Ip (有茥性), Ips (亜有茎性), Is (無菱性) とし, さらに無菱性のう ち平坦なるのをIIa，中心宿凹を有する平坦なるのを IIa+IIc として 5 型に分類した。

1）腫崲平均最大径

$\mathrm{sm}$ 癌の平均最大径は $2.46 \mathrm{~cm}$ であった。他群との比 較を表 3 に示す，各群間にはそれぞれ統計学的有意差 （p<0.01）を認めた。

表 1 平均年齢

\begin{tabular}{c|l}
\hline $\mathrm{m}$ & $61.4 \pm 11.2$ 歲 \\
$\mathrm{sm}$ & $62.0 \pm 10.7$ \\
$\mathrm{pm}$ & $62.3 \pm 13.3$ \\
$\mathrm{ss}, \mathrm{a}, \mathrm{BI} F$ & $58.6 \pm 13.1 \quad(\mathrm{M} \pm \mathrm{SD})$ \\
\hline
\end{tabular}

表 2 男女比

\begin{tabular}{|c|c|c|c|}
\hline & 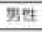 & 25 & Et \\
\hline $\mathrm{m}$ & 45 & 20 & 65 का \\
\hline $\mathrm{sm}$ & 55 & 62 & 117 \\
\hline $\mathrm{pm}$ & 100 & 82 & 182 \\
\hline Ss, a, 12 T & 241 & 156 & 397 \\
\hline it & 441 & 320 & 761 \\
\hline
\end{tabular}

表 3 隀瘍平均最大径

\begin{tabular}{c|l}
\hline$m$ & $1.29 \pm 1.65 \mathrm{~cm}$ \\
$\mathrm{sm}$ & $2.46 \pm 1.65$ \\
$\mathrm{pm}$ & $4.15 \pm 1.75$ \\
ss, $\mathrm{a}_{1}$ 以下 & $5.79 \pm 2.25 \quad(M \pm S D)$ \\
\hline
\end{tabular}

（各群間有意差あり $P<0.01 ）$

表 4 組織型

\begin{tabular}{|c|c|c|c|c|c|c|c|c|}
\hline & 要分化 & 中分化 & 低分化 & 粘源淛 & 印桭細胞惠 & 末分化萬 & 画平上皮达 & tt \\
\hline$m$ & $\begin{array}{c}65 \\
(97.0)\end{array}$ & $\begin{array}{c}2 \\
(3.0)\end{array}$ & 0 & 0 & 0 & 0 & 0 & 67 \\
\hline $\mathrm{sm}$ & $\begin{array}{c}103 \\
(83.7)\end{array}$ & $\begin{array}{c}19 \\
(15.4)\end{array}$ & 0 & $\begin{array}{c}1 \\
(0.8)\end{array}$ & 0 & 0 & 0 & 123 \\
\hline pm & $\begin{array}{c}137 \\
(75.3)\end{array}$ & $\begin{array}{c}35 \\
(19.2)\end{array}$ & $\begin{array}{c}5 \\
(2.7)\end{array}$ & $\begin{array}{c}2 \\
(1.1)\end{array}$ & $\begin{array}{c}2 \\
(1.1)\end{array}$ & $\begin{array}{c}1 \\
(0.5)\end{array}$ & 0 & 182 \\
\hline$s s, a_{1}$ bSF & $\begin{array}{c}328 \\
(81.2)\end{array}$ & $\begin{array}{c}37 \\
(9.2)\end{array}$ & $\begin{array}{c}12 \\
(3.0)\end{array}$ & $\begin{array}{c}5 \\
(1.2)\end{array}$ & $\begin{array}{c}11 \\
(2.7)\end{array}$ & $\begin{array}{c}6 \\
(1.5)\end{array}$ & $\begin{array}{c}5 \\
(1.2)\end{array}$ & 404 \\
\hline
\end{tabular}

2)組織型

各群とも高分化腺癌が高率であるが $\mathrm{pm}$ 癌以下の進 行癌に低分化傾向の癌が頻度は少ないながら見られる のに対し，早期癌ではほとんど見られなかった（表 4 ）.

3）癌の局在

$\mathrm{sm}$ 癌は下部直腸 (以下 $\mathrm{Rb}$ ) に46病巣と最も高頻度 であった．Ｓ状結腸（以下 S) より肛門側が106病巣 $(86.2 \%)$ と $\mathrm{m}$ 癌, $\mathrm{pm}$ 癌とともに ss, $\mathrm{a}_{1}$ 以下の進行癌 に比べて高率であった（表 5 ）.

4) $\mathrm{sm}$ 癌の形態と局在

形態別局在頻度を表 6 に示す.いずれの形態も局在 $\mathrm{S}$ より肛門僋に高頻度であり, 結腸特にS $\mathrm{S}$ 有茎性病

表 5 癌の局在

\begin{tabular}{|c|c|c|c|c|c|c|c|c|c|c|c|c|}
\hline & $\mathrm{E}$ & $P$ & Rb & $\mathrm{Ra}$ & Rs & s & D & $T$ & A & $\mathrm{c}$ & v & 此 \\
\hline \multirow[t]{2}{*}{$\mathrm{m}$} & 0 & 1 & 13 & 5 & 12 & 23 & 3 & 6 & 4 & 0 & 0 & 67 㶾果 \\
\hline & \multicolumn{6}{|c|}{$54 / 67=80.6 \%$} & & & & & & \\
\hline \multirow[t]{2}{*}{$s m$} & 0 & 1 & 46 & 16 & 12 & 31 & 2 & 4 & 7 & 3 & 1 & 123 \\
\hline & \multicolumn{6}{|c|}{$106 / 123=86.2 \%$} & & & & & & \\
\hline \multirow[t]{2}{*}{$\mathrm{pm}$} & 0 & 4 & 92 & 22 & 13 & 23 & 4 & 10 & 5 & 9 & 0 & 182 \\
\hline & \multicolumn{6}{|c|}{$154 / 182=84.6 \%$} & & & & & & \\
\hline \multirow[t]{2}{*}{ ss.a.ELF } & 1 & 13 & 66 & 61 & 54 & 81 & 16 & 39 & 35 & 38 & 0 & 404 \\
\hline & \multicolumn{6}{|c|}{$276 / 404=68.3 \%$} & & & & & & \\
\hline
\end{tabular}

表 $6 \mathrm{sm}$ 癌の形態と局在

\begin{tabular}{c|cccccccccc|c}
\hline & $P$ & $R b$ & $R a$ & $R s$ & $S$ & $D$ & $T$ & $A$ & $C$ & $V$ & It \\
\hline Ip & 1 & 4 & 3 & 2 & 12 & 1 & 1 & 1 & 0 & 0 & 25 \\
Ips & 0 & 6 & 6 & 4 & 5 & 1 & 2 & 3 & 0 & 0 & 27 \\
Is & 0 & 14 & 4 & 5 & 5 & 0 & 1 & 1 & 1 & 1 & 32 \\
Ia & 0 & 7 & 2 & 0 & 3 & 0 & 0 & 2 & 2 & 0 & 16 \\
Ia + Ic & 0 & 13 & 1 & 1 & 5 & 0 & 0 & 1 & 0 & 0 & 21 \\
その他 & 0 & 1 & 0 & 1 & 0 & 0 & 0 & 0 & 0 & 0 & 2 \\
\hline 年 & 1 & 45 & 16 & 13 & 30 & 2 & 4 & 8 & 3 & 1 & 123 \\
\hline
\end{tabular}

図 $1 \mathrm{sm}$ 浸潤度分類

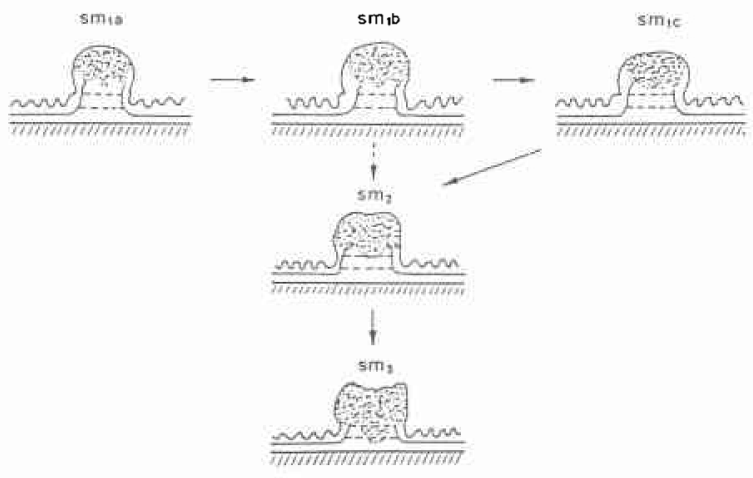

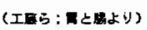


巣が多く, 直腸特に Rbに無茥性の病巣とりわけ IIa, $\mathrm{IIa}+\mathrm{IIC}$ の頻度が高く, 盲腸 (以下 C) ではすべてが無 茎性（Isないし IIa）であった。

5）浸潤度分類別頻度とその大きさ

当科で採用している sm 浸潤度分類 (図 1 $)^{10}$ に従っ て分類すると, その頻度（病巣数）は $\mathrm{sm}_{1} \mathrm{a}: 13, \mathrm{sm}_{1}$ $\mathrm{b}: 8, \mathrm{sm}_{1} \mathrm{c}: 20, \mathrm{sm}_{2}: 33, \mathrm{sm}_{3}: 49$ であり, その大き さは表 7 の゙とくであった，sm 癌に限って見ると，大 きさと浸潤度の間に相関はみられなかった。

\section{6) 形態と浸潤度}

形態と浸潤度の関係を表 8 に示す. Ip は $\mathrm{sm}_{1}$ が約半 数を占めるのに対し, Ips では半数近くが $\mathrm{sm}_{2}$, Is で半 数近くが $\mathrm{sm}_{3}$ であったが何れるかなりばらつきがみら れた. IIa で約半数, IIa +IIc では大多数が $\mathrm{sm}_{3}$ の深㬝 まで達していた。 また少数ながら Ipでも深層に達する もの, IIa+IIcでも比較的浅層に留まるものなど例外

表 $7 \mathrm{sm}$ 浸潤度分類別頻度とその大きさ

\begin{tabular}{|c|c|c|}
\hline & 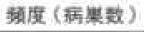 & 大きさ $(M \pm S O)$ \\
\hline smia & 13 & $2.45 \pm 1.88 \mathrm{~cm}$ \\
\hline$s m+b$ & 8 & $2.25 \pm 0.48$ \\
\hline $\operatorname{smic}$ & 20 & $2.67 \pm 1.55$ \\
\hline$s m_{2}$ & 33 & $1.95 \pm 0.98$ \\
\hline $\mathrm{sms}$ & 49 & $2.75 \pm 1.99$ \\
\hline
\end{tabular}

表 $8 \mathrm{sm}$ 癌の形態と浸潤度

\begin{tabular}{|c|c|c|c|c|c|c|}
\hline & $s m_{1 a}$ & $s m_{1} b$ & $s m_{1 c}$ & $\mathrm{sm}_{\mathbf{2}}$ & $s m_{1}$ & तो \\
\hline Ip & 5 & 2 & 6 & 9 & 3 & 25 两黑 \\
\hline Lps & 3 & 2 & 6 & 11 & 5 & 27 \\
\hline is & 3 & 2 & 6 & 7 & 14 & 32 \\
\hline da & 1 & 1 & 1 & 4 & 9 & 16 \\
\hline $\mathbb{H a}+\mathbb{H e}_{c}$ & 1 & 1 & 0 & 2 & 17 & 21 \\
\hline Forte & 0 & 0 & 1 & 0 & 1 & 2 \\
\hline Ht & 13 & 8 & 20 & 33 & 49 & 123 \\
\hline
\end{tabular}

図 $2 \mathrm{sm}$ 癌の形態, 大きさ, 浸潤度の関係

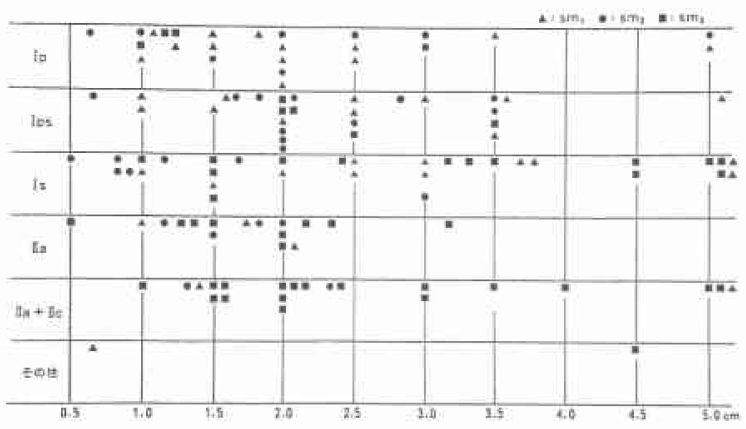

的な病巣も散見された。

7) 形態, 大きさ, 浸潤度の関係

大きさと漫潤度に形態を加味して検討した結果を図 2 に示した. Ipではその大ささに関係なく比較的浅層 に留まるものが多く，Ips は浸潤度の推定は難しいが， Is ではその大きさが $3 \mathrm{~cm}$ を越えるものの約半数は sm の深層 $\left(\mathrm{sm}_{3}\right)$ まで浸潤していた，またIIa 拉よびIIa十 IIcではその大きさに関係なく深層まで達するすのが 多かった。

8）形態と脈管侵襲，リンパ節転移陽性率 $\mathrm{sm}$ 癌全体のリンパ管侵襲陽性率は $21.4 \%$, 静脈侵 襲陽性率は $19.7 \%$ ，リンパ節転移陽性率 $9.4 \%$ あるっ た.これを形態別に示すと表 9 こごとくなる、いずれ も Ip で陽性率が低く, Is, IIa, IIa +IIc と形態が変化 するにつれて陽性率が高くなることが特徴であった。 しかし，どの形態にす予後悪性因子が出現し得ること も注目すべき点であった。

9）浸潤度と脈管侵襲，リンパ節転移陽性率 $\mathrm{sm}_{1} \mathrm{a}$ には予後悪性因子は見られなかった（表10）。 また拈括むね浸潤度と各悪性因子陽性率は相関してお り, $\mathrm{sm}_{1} \mathrm{~b}, \mathrm{sm}_{1} \mathrm{c}, \mathrm{sm}_{2}$ では約 4 例に 1 例, $\mathrm{sm}_{3}$ では 2 例

表 9 形態と $\mathrm{ly} \cdot \mathrm{v} \cdot \mathrm{n}$ 陽性率（HE 染色）

\begin{tabular}{|c|c|c|c|c|c|}
\hline ( ) 5 步 & ey $(+)$ & $v(t)$ & $\pi(+)$ & \multicolumn{2}{|c|}{ 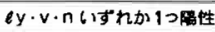 } \\
\hline (23) & 2 & 2 & 1 & $4 / 23$ & $(17.4 \%)$ \\
\hline los & 4 & 3 & 1 & $7 / 26$ & $(26,9 \%)$ \\
\hline${ }^{15}(29)$ & 7 & 3 & 2 & $8 / 29$ & $(27.6 \%)$ \\
\hline IIa $(16)$ & 5 & 5 & 0 & $8 / 16$ & $(50.0 \%)$ \\
\hline $\begin{array}{l}\square a+\pi c \\
\text { (21) }\end{array}$ & 5 & 9 & 6 & $12 / 21$ & (57.1\%) \\
\hline $\begin{array}{l}\text { その他 } \\
\text { (2) }\end{array}$ & 2 & 1 & 1 & $2 / 2$ & $(100 \%)$ \\
\hline $\begin{array}{l}117 \text { 看皆 } \\
(111 \text { 茢) }\end{array}$ & $\begin{array}{l}25 \\
(21.4 \%)\end{array}$ & $\begin{array}{l}23 \\
(19.7 \%)\end{array}$ & $\begin{array}{l}11 \\
(9.4 \%)\end{array}$ & $\begin{array}{l}41 \\
(35.0 \%)\end{array}$ & \\
\hline
\end{tabular}

表10 浸潤度と $\mathrm{ly} \cdot \mathrm{v} \cdot \mathrm{n}$ 陽性率（HE染色）

\begin{tabular}{|c|c|c|c|c|c|}
\hline ( ) 病䡃 & $e y(+)$ & $v(x+)$ & $n(+)$ & $e y \cdot v \cdot n 6$ & れか イっ陪泩 \\
\hline $\begin{array}{l}\mathrm{sm}_{1} \mathbf{a} \\
(12)\end{array}$ & 0 & 0 & 0 & $0 / 12$ & $\left(\begin{array}{ll}0 & \boldsymbol{x}\end{array}\right)$ \\
\hline $\begin{array}{l}s m_{1 b} \\
(8)\end{array}$ & 1 & 3 & 1 & $3 / 8$ & $(37.5 \%)$ \\
\hline $\begin{array}{l}\mathrm{sm}_{\mathrm{ic}} \\
\quad(18)\end{array}$ & 3 & 1 & 1 & $4 / 18$ & $(22.2 \%)$ \\
\hline $\begin{array}{l}s m_{2} \\
(31)\end{array}$ & 6 & 4 & 3 & $8 / 31$ & $(25.8 \%)$ \\
\hline $\begin{array}{l}\mathrm{sm}_{3} \\
\quad(48)\end{array}$ & 15 & 15 & 6 & $26 / 48$ & $(54.2 \%)$ \\
\hline $\begin{array}{l}117 \text { 病柴 } \\
\text { (111例) }\end{array}$ & $\begin{array}{l}25 \\
(21.4 \%)\end{array}$ & $\begin{array}{l}23 \\
(19.7 x)\end{array}$ & $\begin{array}{l}11 \\
(9.4 \%)\end{array}$ & $\begin{array}{l}41 \\
(35.0 \%)\end{array}$ & \\
\hline
\end{tabular}


に1例が何らかの予後悪性因子を有していた。中でも リンパ節転移陽性率と浸潤度の関係は明らかで $\mathrm{sm}_{3}$ に 限ってみればその陽性率は48病巣中 6 病巣 $(12.5 \%)$ と決して無視できない値であった。

10）リンパ節転移陽性例

リンパ節転移陽性例は111例中11例（117病巣中11病 巣)であった，その症例の詳細を表11に示した，比較 的若年者に多く, IIa $+\mathrm{IIc}, \mathrm{sm}_{3}$ が半数以上占めておう, リンパ管侵襲陽性率は11例中 6 例 $(54.5 \%)$ であった。 またリンパ管侵襲陰性で静脈侵襲陽性例が 3 例みられ た、脈管侵襲陰性例が 2 例見られたがいずれも $\mathrm{sm}_{3}$ の 深層浸潤を示す症例であった。リンパ節転移に関して は $\mathrm{n}_{2}(+)$ のすが 2 例あった。

11）リンパ管侵襲とリンパ節転移

リンパ管侵襲陽珄例においてはリンパ節転移陽性例 8 例 $(32.0 \%)$ ，陰性例17例（68.0\%)，一方リンパ管 侵襲陰性例ではリンパ節転移陽性例 3 例 (3.3\%)，陰 性例89例 $(96.7 \%$ )であり，両者間には統計学的有意 差（p<0.01）が認められた（表12）。

12）静脈侵襲陽性例と血行転移

静脈侵襲陽性例を示した(表13).23病巣中 IIa, IIa+
IIc が14病巣, $\mathrm{sm}_{3}$ が15病巣占めていた，比較的小さい 病巣が多く含まれていることも特徽的であった．経過 年数に相違はあるが血行性転移は今のところ経験して

表11 リンパ節転移陽性例

\begin{tabular}{|c|c|c|c|c|c|c|c|c|c|}
\hline is & 贵 & 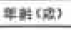 & 融 & 至象 & 大きさ $(\mathrm{cm})$ & 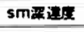 & n-number & oy $v$ & 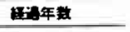 \\
\hline 1 & $M$ & 71 & s & Ips & 2.0 & sma & $n_{1}$ & $(+)(-)$ & 脌 2朋 \\
\hline 2 & $F$ & 12 & s & Ip & 3.5 & $s m_{1 c}$ & $n_{1}$ & $(+)(-)$ & 3年 3 \\
\hline 3 & M & 62 & s & Is & 0.8 & $\mathrm{sm}_{2}$ & $n_{1}$ & $(+)(-)$ & 10年 3 \\
\hline 4 & $F$ & 52 & Rb & Ia $a+\mathbb{I} c$ & 2.3 & $\mathbf{s m} \mathbf{m}_{2}$ & $n_{2}$ & $(-)(+)$ & 6年 1 力月 \\
\hline 5 & $F$ & 42 & s & $\mathbb{I a}+\mathbb{I} c$ & 1.4 & $\operatorname{sm}_{1} b$ & $n_{1}$ & $(-)(+)$ & 4年1008 \\
\hline 6 & м & 38 & s & lps $+\| \mathbf{a}$ & 4.5 & $\mathrm{sm}_{3}$ & $n_{1}$ & $(-)(-)$ & 1年 7朋 \\
\hline 7 & $F$ & 54 & $\mathrm{Rb}$ & is & 3.3 & $\mathrm{sm}_{3}$ & $n_{1}$ & $(+)(-)$ & 3年 1 胡 \\
\hline 8 & $\mathbf{F}$ & 61 & $\mathrm{Ra}$ & $\mathbb{\|} a+\mathbb{\| c}$ & 1.5 & $s m_{2}$ & $n_{1}$ & $(-)(-)$ & 4年 6 加 \\
\hline 9 & $M$ & 55 & $s$ & $I a+I c$ & 1.0 & $\mathrm{sm}_{3}$ & $n_{2}$ & $(+)(t)$ & $?$ \\
\hline 10 & $M$ & 43 & Rs & $\mathbb{Z a}+\mathbf{I c}$ & 2.1 & $\mathrm{sm}_{3}$ & $n_{1}$ & $(+)(+)$ & 39 7 蚂 \\
\hline 11 & $M$ & 75 & Rb & $\mathrm{Da}+\mathbf{I c}$ & 1.6 & $\mathbf{s m}$, & $n_{1}$ & $(-)(+)$ & ） 1 加 \\
\hline
\end{tabular}

表12 リンパ答侵襲とリンパ節転移

\begin{tabular}{|c|c|c|c|}
\hline & 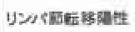 & 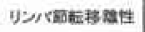 & 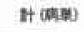 \\
\hline 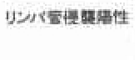 & $\stackrel{8}{(32.0 \%)}$ & $\begin{array}{l}17 \\
(68.0 \%)\end{array}$ & 25 \\
\hline 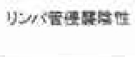 & $(3.3 x)$ & $\begin{array}{l}89 \\
(96.7 \%)\end{array}$ & 92 \\
\hline H & 11 & 106 & $117(1114$ \\
\hline
\end{tabular}

表13 V (+) 症例（22例23病変）

\begin{tabular}{|c|c|c|c|c|c|c|c|c|c|}
\hline $\mathrm{Na}$ & 性 & 年䀫(萿) & 局在 & 形䀠 & 大きさ (c⿴囗十) & sm深逢度 & 程週年数 & 血行珄転移 & リンパ即転移 \\
\hline 1 & $\mathrm{~F}$ & 71 & $\mathrm{Rb}$ & Ips & 2.0 & $s m i b$ & 5 年 3 か月 & $(-)$ & $(-)$ \\
\hline 2 & $M$ & 62 & S & Is & 0.8 & $s m_{2}$ & 10年 1か月 & $(-)$ & $(+)$ \\
\hline 3 & $F$ & 52 & $\mathrm{Rb}$ & $\Pi \mathrm{I}+\Pi \mathbf{c}$ & 2.3 & $\mathrm{sm}_{2}$ & 5 年10か月 & $(-)$ & $(+)$ \\
\hline 4 & $F$ & 59 & $\mathrm{Rb}$ & Ila + Ilc & 1.5 & $\mathrm{sm}_{3}$ & 4 年 8 加月 & $(-)$ & $(-)$ \\
\hline 5 & $M$ & 68 & Rs & Ips & 2.0 & $\mathrm{sm}_{3}$ & 4 年 6 か月 & $(-)$ & $(-)$ \\
\hline 6 & $F$ & 42 & $\mathrm{~s}$ & $\Pi \mathrm{Il}+\Pi \mathrm{lc}$ & 1.4 & $\sin , b$ & 4 年10か月 & $(-)$ & $(+)$ \\
\hline 7 & $F$ & 72 & C & Пla & 1.2 & $\mathrm{sm}_{2}$ & 4 年 6 加月 & $(-)$ & $(-)$ \\
\hline 8 & $F$ & 59 & $\mathrm{~s}$ & Ip & 1.0 & $\mathrm{sm}_{3}$ & 4年1加月 & $(-)$ & $(+)$ \\
\hline 9 & $M$ & 38 & $\mathrm{~s}$ & Ips $+11 a$ & 4.5 & $\mathrm{sm}_{3}$ & 1 年 4 か月 & $(-)$ & $(+)$ \\
\hline 10 & $M$ & 56 & s & Па & 2.3 & $\mathrm{Sm}_{3}$ & 1年 1 か月 & $(-)$ & $(-)$ \\
\hline 11 & $F$ & 61 & $R b$ & Ila + Ic & 3.0 & $\mathrm{sm}_{3}$ & 7 か月 & $(-)$ & $(-)$ \\
\hline \multirow[t]{2}{*}{12} & $F$ & 70 & Ra & Па & 3.2 & $\mathrm{sm}_{3}$ & 3年 & $(-)$ & $(-)$ \\
\hline & & & Ra & [la & 1.7 & $\mathrm{sm}_{2}$ & 3年 & $(-)$ & $(-)$ \\
\hline 13 & $F$ & 72 & D & Ips & 2.1 & $\mathrm{sm}_{3}$ & 2 年 5 か月 & $(-)$ & $(-)$ \\
\hline 14 & $M$ & 60 & $R b$ & Ila & 2.1 & $s m_{1} b$ & 1 年 & $(-)$ & $(-)$ \\
\hline 15 & $M$ & 55 & $S$ & Ila + IIc & 1.0 & $\mathrm{sm}_{3}$ & $?$ & $?$ & $(+)$ \\
\hline 16 & $M$ & 43 & Rs & $\Pi a+\square c$ & 2.1 & $\mathrm{sm}_{3}$ & 3年7 か月 & $(-)$ & $(+)$ \\
\hline 17 & $F$ & 73 & $S$ & Is & 2.0 & $\mathrm{sm}_{3}$ & 5 年 7 か月 & $(-)$ & $(-)$ \\
\hline 18 & M & 54 & $\mathbf{R b}$ & Is & 5.0 & $\mathrm{sm}_{3}$ & $?$ & $?$ & $(-)$ \\
\hline 19 & $F$ & 45 & $\mathbf{R b}$ & Ila + Ilc & 2.2 & $\mathrm{sm}_{3}$ & 2 年 5 か月 & $(-)$ & $(-)$ \\
\hline 20 & $F$ & 49 & Ro & $\Pi a+\Pi c$ & 2.0 & $\mathrm{sm}_{3}$ & 5 年 & $(-)$ & $(-)$ \\
\hline 21 & $M$ & 75 & $R b$ & 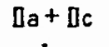 & 1.6 & $\mathrm{sm}_{3}$ & 1 b月 & $(-)$ & $(+)$ \\
\hline 22 & $M$ & 47 & $\mathbf{S}$ & Ip & 2.0 & STinc & 2 か月 & $(-)$ & $(-)$ \\
\hline
\end{tabular}


表14 再発死亡症例

\begin{tabular}{|c|c|c|c|c|c|c|c|c|c|}
\hline $\mathrm{Na}$ & 性 & $\begin{array}{l}\text { 年政 } \\
\text { (藏) }\end{array}$ & 局在 & 形堭 & $\begin{array}{l}\text { 大きさ } \\
(\mathrm{cm})\end{array}$ & $\begin{array}{c}\text { sm } \\
\text { 梁進度 }\end{array}$ & 喜性因子 & 再無形式 & 桯通年数 \\
\hline 1 & $F$ & 42 & s & is & 3.5 & $\mathrm{sm}_{1 \mathrm{c}}$ & $n(t)$ & 用所再発 & 3年 3 \\
\hline 2 & $M$ & 71 & Rs & Is & 1.5 & $\mathrm{sm}$, & (?) & 局所再铎 & 4年 $7 b$ 朋 \\
\hline 3 & $M$ & 75 & Ra & Is & 4.5 & $\mathrm{sm}_{3}$ & aw $(t)$ & 局所再佥 & 1年10 朋 \\
\hline 4 & $F$ & 60 & RD & $1 p$ & 1.2 & $\mathrm{sm}_{3}$ & (?) & 眉所再我 & 6年 \\
\hline
\end{tabular}

いない.しかしリンパ節転移陽性例が 8 例 $36.4 \%$ に認 められた。

13）再発死亡症例の検討

117例中 9 例は予後追跡不能であり，これを除いた 108例中死亡例は10例であった.この10例のうち癌死と 確認されたのは 4 例であり，いずれも腸切除を受けた 症例であった(表14). 再発形式はいずれも局所再発で あり， 1 例はリンパ節転移陽性例， 1 例は aw $(+)$, あとの 2 例は局所切除例のためリンパ節転移の有無は いずれる不明であったが， $\mathrm{sm}_{3}$ の樑層浸潤を示す症例 であった。

\section{考察}

大腸 $\operatorname{sm}$ 癌は進行癌と比較して，大きさがある程度 深達度の予測に有用であること，組織型で高分化腺癌 がほとんどを占めて打り予後悪性度の高い低分化傾向 の癌を早期の段階で発見することが困難であること， 局在は Sより肚門側の頻度が高く特に Rbに多いこ と, 形態で $\mathrm{S} に$ 有茥性病巣が，直腸，盲腸に無茥性の 病巣 (Is, IIa, IIa+IIc)が多いことなどが特徴として 挙げられる。大きさが深達度と相関することは予想さ れるが，注目すべき点は sm癌だけに限ってみれば浸 潤度との間に関係が見られないことである。これは多 くの sm 癌が病巣の中に腺腫成分を含んでいるためで あり，その量により大きさが左右されるからである ${ }^{11}$. 局在がSより肛門側に高頻度であるが,これはより肛 門側の病巣で出血などの症状に患者自身が気付きやす いこと, 診療側でも病巣を発見しやすいことがその理 由と考光られる。早期癌を含め大腸ポリープの形態に は腸管の蠕動が大きく左右すると想像される。蠕動運 動の大きい部分, 特に S に有茥性病巣を形成しやすい とされている従来の報告 ${ }^{12)}$ 同様の所見が本集計です 見られる。一方, 癌発生より進行癌に至るまでには複 数の発育過程があるとされている(13)が，ある局在に一 定の形態が多くみられることは局在別にたどりや寸い 発育過程が有ることを示唆している。

大腸 sm 癌を論ずる場合, 追加腸切除の適応条件と
その切除範囲が最も大きな問題である，現在，大腸癌

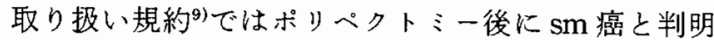
した場合は原則として追加腸切除を検討する必要があ り, 特に以下の所見があれば追加腸切除の適応として いる。すなわち、

(1) 明かな脈管内癌浸潤

(2) 低分化腺癌あるいは未分化癌

(3) 断端近傍までの massiveな癌浸潤

の 3 所見である。一見簡潔明瞭とも思えるこれらの条 件も実際には多くの問題を含んでいる.

(1)に関して，リンパ管侵襲陽性例にリンパ節転移が 多いことは従来より報告14)されているが，静脈侵襲陽 性例においてもリンパ節転移陽性率の高いことが報 告8)されている，今回我々のデータでもこれを支持す る結果が得られており，検索標本で腫瘍近傍に静脈内 腫場塞栓の見られることがしばしばあることからも， リンパ管侵襲が陰性でも静脈侵襲が陽性ならリンパ節 郭清を伴う追加切除の適応とすることに異論はない. ただ問題となるのは sm 癌の脈管侵襲陽性率が報告施 設によりかなり差があること， また実際著者らが標本 検索をする上でも判定に迷う症例があることなと，検 索方法や診断基準(診断能力を含めて)の統一性が久け ている点である。特に規約に記載されている明らかな 陽性症例だけの拾い上げではかなりの false negative が存在するものと思われ，また現実に脈管侵襲院性の リンパ節転移陽性症例が多く報告されていることがこ れを裏付けている，林田ら ${ }^{15}$ は脈管侵襲判定の補足と して今井 ${ }^{16)}$ の提唱した簇出が $\mathrm{sm}$ 癌でも有用であった と述べているが, 今後この様な新しい検索, 判定方法 の導入による診断の正確さが要求される.

(2)については Lockhart-Mummery and Dukes ${ }^{11}$ が 深達度にかかわらずその悪性度が高い故に根治術の適 応と指摘し，その後 Morson ら 17)18)がこれを支持する 報告をしている、残念ながらわれわれはこれらの組織 型をもつ早期癌の経験に之しく悪性度を検討すること は出来ないが，逆にこれらの組織型を呈する早期癌を 発見できないことが彼らの言う通り進行速度の早さを 物語っているとも考えられ，今までに経験した低分化， 末分化進行癌の予後が極めて不良である点からみても 追加腸切除の適応とすることは妥当と考劣る。

(3)についての問題は, どれくらいの癌浸潤で mas sive と称し, どれくらいの距離をさして断端近傍とす るのか明確な定義がなされていないことである。従来 より $\mathrm{sm}$ 領域の“癌量”が予後に影響することは指摘さ 
れていたが，その表現方法はまちまちであり何れも抽 象的な表現であった。この点を具体的に表現した論文 としては Coutsoftides ら ${ }^{19) か ゙ ホ ゚ リ ヘ ゚ ク ト ミ 一 さ れ た ~}$ 有茎性病変の茎部を 3 等分して浸潤量を表現したも の, 工藤ら ${ }^{10)}$ が sm 領域を 3 等分しさらに横への広が りを加劣ることで定義した浸潤度分類などがある。後 者では予後悪性因子との相関性が密で有用性の高いこ とが報告されて却り，かなり頻度が高いと予想される 脈管侵襲の false negative を避ける意味でも当科では この浸潤度分類を手術適応の重要な因子としている.

この浸潤度分類と諸因子の関係を検討した結果で は，大きさに関して関係は認められないものの, 形態 ではかなり相関がみられ浸潤度の推定には有用であ る。さらに形態と大きさの 2 因子の組合せはより正確 な情報を与えてくれるが，それでも例外的な病巣もあ り, 浸潤度の正確な診断には組織学的検索が必要と思 われる。

浸潤度と予後悪性因子の関係では $\mathrm{sm}_{1} \mathrm{a}$ で前回の報 告 ${ }^{10)}$ 同様悪性因子はみられないが $\mathrm{sm}_{1} \mathrm{~b}, \mathrm{sm}_{1} \mathrm{c}, \mathrm{sm}_{2}$ で 約 4 例に 1 例, $\mathrm{sm}_{3}$ で約 2 例に 1 例とかなり高い頻度 で予後悪性因子を有しておりまたりンパ節転移も $\mathrm{sm}_{1}$ bより出現することから，従来より採用してきた $\mathrm{sm}_{1} \mathrm{~b}$ から根治手術の適応とした当科の治療方針は生命予後 優先といら点からは妥当であると考兄られる.

形態と予後悪性因子の関係では, 形態が浸潤度と相 関があることから当然ある程度の推定は可能である が，しかし浸潤度と形態の対応は必ずしも一致せず， このためあらゆる形態に予後悪性因子が出現しえるこ とに注意すべきである。

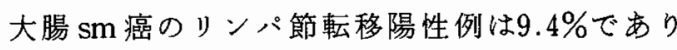
$10 \%$ 前後とする諸家の報告と一致する. 形態 IIa + IIc， 浸潤度 $\mathrm{sm}_{3}$, 脈管侵襲陽性例で危険率が高く $\mathrm{n}_{2}(+)$ の症例もあることにより, 郭清は原則として最低 $\mathrm{R}_{2}$ が 必要である。一方, 静脈侵襲陽性例の特徽はIIa および $\mathrm{IIa}+\mathrm{II} c, \mathrm{sm}_{3}$ 症例が多くを占めていることである. 血 行性転移が文献上では数\%あるとされているが，現時 点でわれわれは経験していない，前述したように，静 脈侵襲陽性と同時にリンパ節転移を来している症例が 多いことが注目される。

今回の集計では再発死亡が 4 例あり，それぞれ予後 悪性因子 $\left(\mathrm{sm}_{3}\right.$ あ含めて) を持っていた。頻度が少ない とは言え，対処を䛊れば再発につながる危険があり， 決して早期癌といえどす侮ってはならない。

最後に治療方針につき述べてみたい，当科では従来
上り $\mathrm{sm}$ 浸潤が疑われるがポリペクトミ一出来ない症 例およびポリペクトミーあるいは局所切除で $\mathrm{sm}_{1} \mathrm{~b}$ 以 下の浸潤度を有する病巣に対しては予後悪性因子を有 する危険があることから，生命予後を優先するため局 在に関係なく進行癌に準じた治療を行ってきた。しか し結腸と直腸ではその術後機能障害に大きな差がある ことから武藤ら ${ }^{20)}$, 土屋ら ${ }^{21)}$ と同様に現在は局在別に その方針を決めている。すなわち結腸および Rs, Raに 関しては従来どうり $\mathrm{sm}_{1} \mathrm{~b}$ 以下のすべての症例に対し 進行癌に準じた手術(原則として結腸は $\mathrm{R}_{3}, \mathrm{Rs}$ 抢よび $\mathrm{Ra}$ では $\mathrm{R}_{2}$ )を行っている。つまり $\mathrm{sm}$ 浸潤度分類 $\mathrm{sm}_{1}$ b以下を sm massive として取り扱っている. Rbに関 しては術式を工夫してできるだけ人工肚門の造設を避 ける方針をとっている，われわれの経験では sm 癌の 壁内浸潤はせいぜい $0.5 \mathrm{~cm}$ であることより，切除断端 は1cm あれば十分と考壳ている。また $\mathrm{Rb} の \mathrm{sm}$ 癌で (たとえ $\mathrm{pm}$ までの症例を含めたとしても)下直腸リン パ節, 閉鎖リンパ節に転移を来した症例はない(图 3). 一方, 経肛門的吻合術式22)用いれば歯状線から $1 \mathrm{~cm}$ のレベルで切断してる肚門機能温存が可能である.し たがって $\mathrm{Rb}$ で腫場下縁が歯状線より $2 \mathrm{~cm}$ 以上口側で あれば $\mathrm{sm}_{1} \mathrm{~b}$ 以下の $\mathrm{sm}$ 症例に対し結腸肛門吻合術を 用いた根治術の適応としている。ただし肛門側切除断 端 (AW) は最低限 $1 \mathrm{~cm}$ あれば良しとし，閉鎖リンパ 節の郭清は原則として行わない。腫瘍下縁がこれより

因 3 局在 $\mathrm{Rb}$ ( $\mathrm{sm}$ 35例, $\mathrm{pm} 71$ 例）直腸切断術施行 例のリンパ節転移度

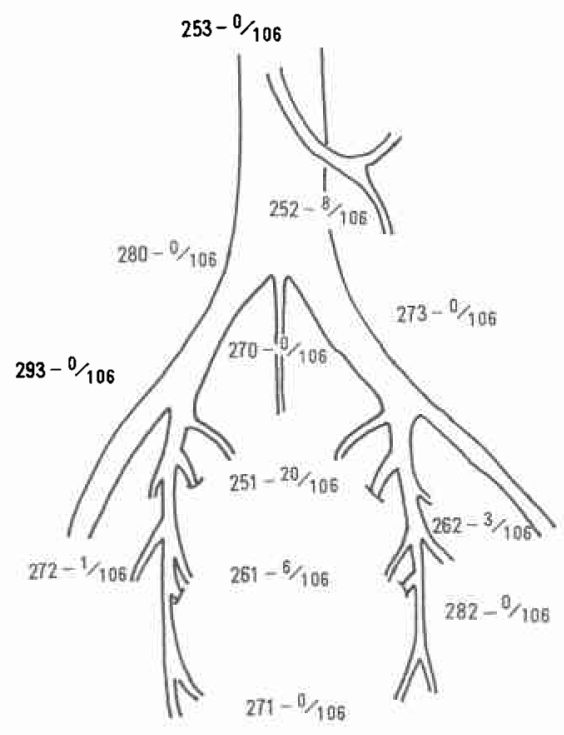


図 $4 \mathrm{sm}$ 癌の治療方針

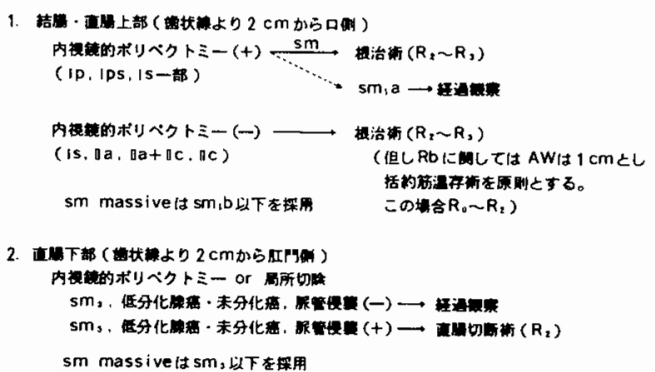

肛門側にあり追加切除が必要な場合，腹会陰式直腸切 断術の適応となる.しかしこの場合, $\mathrm{sm}_{2}$ までの症例の うち脈管侵襲陰性でリンパ節転移を来した症例の経験 はなく, $\mathrm{sm}_{3}$ では脈管侵襲陰性でもリンパ節転移陽性 の症例があることより， $\mathrm{sm}_{3}$ は手術適応とするが $\mathrm{sm}_{2}$ までであれば脈管侵襲陽性でない限り追加切除せず縤 重な経過観察を行う方針をとっている(図4)。この治 療方針にしたがうと，sm癌に対する人工肛門造設術 はほとんどの症例で避けられると考えられる。

\section{結語}

大腸 $\mathrm{sm}$ 癌117例，123病巣の検討より以下の結論を 得た。

1）大腸癌の大きさは深達度と比例するが， sm 癌で は腺腫成分の混在により浸潤度との関係は見られな W.

2)組織型では進行癌に見られるよらな低分化傾向 の癌が認められない. その理由はこれらの癌の進行が 早く早期の段階で発見することが困難なためと考えら れる。

3）局在は Sより肛門側, 特に Rbに高頻度である. また sm 癌の形態には局在により特徵があり，癌の発 育進展は局在別にたどりやすい過程があると考えられ る.

4）形態は浸潤度と相関性があり，これに大きさを加 味するとさらに相関性が増すが，その対応は必ずしす 一致せず浸潤度の判定には組織学的検索を必要とす る.

5）リンパ管侵襲陽性率は $21.4 \%$, 静脈侵襲陽性率は 19.7\%である. 形態別では IIa，IIa+IIc，浸潤度では $\mathrm{sm}_{3}$ で高頻度である。

6）リンパ節転移陽性率は9.4\%である、形態では $\mathrm{IIa}+\mathrm{IIc}$, 浸潤度は $\mathrm{sm}_{3}$ が多い.リンパ節転移陽性例の リンパ管侵襲陽性率は $54.5 \%$ であ,一方，リンパ管
表 15

\begin{tabular}{|c|c|c|}
\hline 建村上病院 & 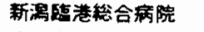 & 夏生逜魚沼病院 \\
\hline 柴立坂町席院 & 满生会新渴総合病陵 & 県立小出病院 \\
\hline 町立相川病院 & 㕵国稀院 & 田第一病院 \\
\hline 兩津市民施院 & 田代唡化器病院 & 南部勄粉合茼院 \\
\hline 军生建佐海総合病院 & 町立菁病院 & 長岡吉田病院 \\
\hline 下越病院 & 立川棇合苪院 & 宗村外科医院 \\
\hline 水原地病院 & 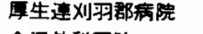 & 県立十日町形 \\
\hline 白相但生病院 & 金沢外科医院 & 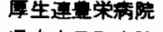 \\
\hline 県立加茂病脿 & 新渴労災病院 & 県立六日 \\
\hline 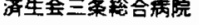 & 燕労災病咾 & 新渴大学第一病理 \\
\hline
\end{tabular}

侵襲陽性例のリンパ節転移陽性率は $32.0 \%$, 陰性例の それは3.3\%である。

7) 癌死は 4 例確認されて扣り， $\mathrm{n}(+)$ が 1 例, aw (十) が 1 例, $\mathrm{sm}_{3}$ が 2 例であり, 再発形式はいずれも 局所再発である。

8） $\mathrm{sm}$ 癌の治療は進行癌に準じて行うことを原則 とするが, 術後機能障害の面から局在により方釬を変 えるべきである．特に人工肛門造設は根治性が得られ るなら極力避けるべきであり，これはほとんどの直腸 $\mathrm{sm}$ 癌症例において可能と考えられる.

最後に今回貴重な資料を提供いたたきさした県内関連施 設（表15）の先生方に深謝いまします。

$$
\text { 文献 }
$$

1) Lockhart-Mummery HE, Dukes CE: The surgical treatment of malignant rectal polyps. Lancet 2:751-756, 1952

2) Shatney $\mathrm{CH}$, Lober PH, Gilbertson VA: The treatment of peduculated adenomatous colorectal polyps with focal cancer. Surg Gynecol Obstet $139: 845-850,1974$

3) Wolff WI, Shinya H: Difinitive treatment of "malignant" polyps of the colon. Ann Surg $182: 516-525,1975$

4) Morson BC, Whiteway JE, Jones EA et al : Histopathology and prognosis of malignant colorectal polyps treated by endoscopic polypectomy. Gut $25: 437-444,1984$

5) Colacchio TA, Forde, KA, Scantebury VP: Endoscopic polypectomy. Inadequate treatment for invasive colorectal carcinoma. Ann Surg $194: 704-707,1981$

6) 石井慶太, 岡部 聡, 中島和美注か：大腸の早期癌 の検討。日消外会誌 $19: 2050-2056,1986$

7) 西田 修, 井斉偉矢, 佐藤直樹 例の病態および治療. 日消外会誌 $20: 1928$ $-1932,1987$

8）武藤徽一郎：大腸 $\mathrm{sm}$ 癌；アンケート集計報告と その考察。胃と腸 $18: 851-855,1983$ 
9）大腸癌研究会編：臨床・病理大腸癌取り扱い規約. 改訂第 4 版，金原出版，東京， 1985

10）工藤進英, 曾我 淳, 下田 聡ほか：大腸 $\mathrm{sm}$ 癌の sm 浸潤の分析と治療方針一sm 浸潤度分類につい て一. 胃之腸 $19: 1349-1356,1984$

11) Morson BC, Dawson IMP: Gastrointestinal Pathology. Second edition. Blackwell Scientific Publications, Oxford, 1979, p654-655

12) Welch CE, McKittrick JB, Behlinger G: Polyps of the rectum and colon and their relation to cancer. N Engl J Med 247 : 959-965, 1952

13）工藤進英, 武藤輝一, 山本睦生ほか：大腸腺腫と早 期癌の形態推移。胃と腸 $20: 903-910 ， 1985$

14) Shatney CH, Lober PM, Sosin H: Metastasis from a pedunculated adenomatous colonic polyp with focally invasive carcinoma. Dis Colon Rectum 18:67-71, 1975

15）林田啓介, 磯本浩晴, 白水和雄ほか：大腸 sm 癌の 検討一とくに脈管侵襲と簇出について一，日本大
腸肛門病会誌 $40 ： 119-126,1987$

16）今井 環：人体癌腫発育状況の形態学的考察. 福 岡医誌 $45: 72-102,1954$

17) Morson $\mathrm{BC}$ : Factors influencing the prognosis of early cancer of the rectum. Proc Roy Soc Med 59:607-608, 1966

18) Morson BC: Policy of local excision for early cancer of the colorectum. Gut $18: 1045-1050$, 1977

19) Coutsoftides T, Sivak MV, Benjamin SP et al: Colonoscopy and the management of polyps containing invasive carcinoma. Ann Surg 188: $638-641,1978$

20）武藤徹一郎, 上谷潤二郎, 沢田俊夫ほか：大腸 sm 癌の取り报い。医と䍘学 $11: 1577-1583 ， 1984$

21）土屋周二, 大木繁男：隆起型大腸早期癌の治療と 予後. 消外 7:1415-1419，1984

22) Parks AG: Transanal technique in low rectal anastomosis. Proc Roy Soc Med 65: 975-976, 1972 